\title{
PERSALINAN PREMATUR KARENA KURANGNYA VITAMIN D
}

\author{
Aulia Ridla Fauzi* \\ *Dosen Prodi D3 Kebidanan STIKes Muhammadiyah Ciamis \\ Email: auliaridlafauzi@gmail.com
}

\begin{abstract}
Background: Incidence of vitamin D deficiency occurs in many at-risk age groups, including infants with low birth weight, pregnant women. During pregnancy, the possibility of decreasing levels of vitamin $D$ in the body will be very large, which is about $5 \mathrm{ng} / \mathrm{ml}$ from normal levels of vitamin $D$ by $30-60 \mathrm{ng} / \mathrm{ml}$. Vitamin $\mathrm{D}$, which not adequately fulfilled, increases the risk of preeclampsia, gestational diabetes, premature labor, fetal growth retardation, spontaneous abortion, and low birth weight of the baby.

Puepose: To identify the correlation between deficiency vitamin $\mathrm{D}$ and preterm labor.

Methods: literature review method for articles on vitamin $D$ in pregnant women that can reduce the risk of preterm labor ( $<37$ weeks). The inclusion criteria used were the benefits of vitamin $D$ resulting from supplement preparations and also vitamin $D$ resulting from direct exposure to sunlight which can reduce the risk of premature labor and low birth weight babies. Exclusion criteria in the preparation of this article are abstract articles, articles that do not use English and articles that are not full text

Result: There was no significant correlation between deficiency vitamin $D$ and preterm birth but the prevalence was higher among women with term birth.

Conclusion: The prevalence of serum vitamin $D$ deficiency was higher among women with preterm delivery than among those with term delivery. The potential role of prenatal vitamin $D$ supplementation in the prevention of preterm delivery should be further investigated.

Suggestion: Further research needs to be done, especially in Indonesia both in urban and rural areas regarding the content of serum $25(\mathrm{OH}) \mathrm{D}$ by looking at the characteristics of pregnant women and their environment.
\end{abstract}

Keywords: Deficiency Vitamin D, Preterm Labor

\section{ABSTRAK}

Latar Belakang: Kejadian defisiensi vitamin D banyak terjadi pada kelompok usia berisiko, diantaranya adalah bayi dengan berat lahir rendah, ibu hamil dan orang lanjut usia. Kebutuhan gizi ibu hamil terdiri dari makromineral dan mikromineral yang harus dicukupi selama hamil, salah satu kebutuhan mikromineral yang dibutuhkan ibu saat hamil adalah vitamin D. Vitamin D yang tidak tercukupi dengan baik, meningkatkan risiko terjadinya preeklampsia, diabetes gestasional, persalinan prematur, terhambatnya pertumbuhan janin, abortus spontan, serta berat bayi lahir rendah. prematur

Tujuan: Untuk mengetahui hubungan antara kekurangan vitamin $D$ dengan kejadian persalinan

Metode: Metode literature review terhadap artikel-artikel mengenai vitamin $\mathrm{D}$ pada wanita hamil yang dapat menurunkan risiko kejadian persalinan prematur (<37 minggu). Kriteria inklusi yang digunakan adalah manfaat vitamin $D$ yang dihasilkan dari sediaan suplemen dan juga vitamin $D$ yang dihasilkan dari paparan langsung sinar matahari yang dapat menurunkan risiko kejadian persalinan premature dan berat bayi lahir rendah. Kriteria eksklusi dalam penyusunan artikel ini adalah artikel yang abstrak, artikel yang tidak menggunakan Bahasa Inggris dan artikel yang tidak full teks

Hasil: Tidak ada hubungan signifikan antara kekurangan vitamin $\mathrm{D}$ dengan kejadian persalinan prematur namun prevalensi kejadian rendahnya kadar serum vitamin $\mathrm{D}$ ditemukan pada wanita yang bersalin prematur.

Kesimpulan: Prevalensi defisiensi vitamin D serum lebih tinggi pada wanita dengan persalinan prematur dibandingkan mereka yang melahirkan matur. Peran potensial dari suplementasi vitamin $\mathrm{D}$ prenatal dalam pencegahan kelahiran prematur harus diselidiki lebih lanjut.

Saran: Perlu dilakukan penelitian lebih lanjut khususnya di Indonesia baik di perkotaan maupun pedesaan mengenai kandungan serum $25(\mathrm{OH}) \mathrm{D}$ dengan melihat karakteristik dari ibu hamil serta lingkungannya. 


\section{PENDAHULUAN}

Sebuah studi menyebutkan di Dunia ini ada kemungkinan 1 juta orang yang mengalami defisiensi vitamin D (Scarlett, 2003). Kejadian defisiensi vitamin $\mathrm{D}$ banyak terjadi pada kelompok usia berisiko, diantaranya adalah bayi dengan berat lahir rendah, ibu hamil dan orang lanjut usia (van Schoor, N., \& Lips, 2018). Kebutuhan gizi ibu hamil terdiri dari makromineral dan mikromineral yang harus dicukupi selama hamil, salah satu kebutuhan mikromineral yang dibutuhkan ibu saat hamil adalah vitamin D. Sebagian besar sumber vitamin D (80$90 \%$ ) berasal dari kulit yang diinduksi oleh sinar ultraviolet, sebagian lagi berasal dari suplemen vitamin $D$ yang terdistribusi ke beberapa kelenjar seperti skeletal dan sistem reproduksi (Grundmann \& von Versen-höynck, 2011).

Pada masa kehamilan, kemungkinan penurunan kadar vitamin $\mathrm{D}$ dalam tubuh akan sangat besar yaitu sekitar $5 \mathrm{ng} / \mathrm{ml}$ dari kadar normal vitamin D sebesar $30-60 \mathrm{ng} / \mathrm{ml}$, pengukuran kadar vitamin $D$ dilakukan dengan pemeriksaan darah untuk melihat konsentrasi serum 25-hydroxyvitamin D (25(OH)D) (Perez-lopez, et al., 2017). Vitamin D yang tidak tercukupi dengan baik, meningkatkan risiko terjadinya preeklampsia, diabetes gestasional, persalinan prematur, terhambatnya pertumbuhan janin, abortus spontan, serta berat bayi lahir rendah (Nichols, Tinnemore Shannon K \& Huang, 2012). Hal ini didukung penelitian lain bahwa ibu hamil merupakan kelompok risiko tinggi untuk mengalami kejadian defisiensi vitamin $D$ yang akan mengakibatkan pengeroposan tulang, kelainan kekuatan otot, kejadian infeksi pada ibu, kelahiran prematur dan berat bayi lahir rendah (Hague \& Wuister, 2018; Harvey et al., 2014). Berdasar data dari Riskesdas Indonesia, ada kenaikan kelahiran bayi dengan berat lahir rendah (<2500 gram) pada Tahun 2013 sebesar 5,7\% lalu pada Tahun 2018 naik menjadi 6,2\% (Kemenkes RI, 2018).

Faktor yang memengaruhi defisiensi vitamin $D$ diantaranya adalah perubahan fungsi organ yang terlibat dalam proses sintesis $25(\mathrm{OH}) \mathrm{D}$ seperti kulit, hati, ginjal dan usus, selain itu gaya hidup yang menghindari sinar matahari, penggunaan tabir surya dan rendahnya asupan makanan yang mengandung vitamin D (Bolland et al., 2007). Maka untuk itu asupan suplemen vitamin D merupakan strategi yang tepat untuk mencegah dan mengendalikan kekurangan vitamin $\mathrm{D}$ pada ibu hamil dan menyusui yaitu sebanyak $15 \mu \mathrm{g}$ (600IU) per hari atau paling sedikit dalam batas toleransi yaitu 400IU, menurut The Food and Nutrition Board at the Institute of Medicine of the National Academies ( $F$ Perez-Lopez, Pasupuleti et al., 2015.) Asupan vitamin D yang cukup selama kehamilan diperlukan oleh janin untuk melengkapi kebutuhan kalsium dalam masa pertumbuhan dan perkembangan janin (Perez-lopez et al., 2017; Ponsonby, Lucas, Lewis, \& Halliday, 2010). Berdasar uraian di atas, artikel ini disusun untuk melihat apakah vitamin $D$ pada masa kehamilan memengaruhi kejadian kelahiran prematur $\quad<37$ minggu).

\section{METODOLOGI PENELITIAN}

Penyusunan ini menggunakan metode literature review terhadap artikel-artikel mengenai vitamin D pada wanita hamil yang dapat menurunkan risiko kejadian persalinan prematur (<37 minggu). Kriteria inklusi yang digunakan adalah manfaat vitamin $D$ yang dihasilkan dari sediaan suplemen dan juga vitamin D yang dihasilkan dari paparan langsung sinar matahari yang dapat menurunkan risiko kejadian persalinan premature dan berat bayi lahir rendah. Kriteria eksklusi dalam penyusunan artikel ini adalah artikel yang abstrak, artikel yang tidak menggunakan Bahasa Inggris dan artikel yang tidak full teks.

Pencarian artikel dibatasi pada artikelartikel yang berbahasa Inggris dan diakses oleh pencarian internet dari database, diantaranya adalah Medline, Sciencedirect, dan Cochrane database dengan kata kunci vitamin $D$ supplement, pregnancy, dan preterm birth. Artikel yang memenuhi kriteria inklusi dikumpulkan dan diperiksa secara sistematis. Pencarian literatur dilihat dari publikasi artikel lima tahun terakhir (2014-2019). Proses pencarian yang memenuhi syarat sesuai kriteria inklusi dan eksklusi ada sebanyak 4 artikel.

\section{HASIL DAN PEMBAHASAN}

Berdasar dari database pencarian yang dilakukan oleh peneliti, ditemukan ada sebanyak 56 artikel yang sesuai dengan tema, setelah dilakukan screening ditemukan 11 artikel yang tidak dapat diakses dan 34 artikel yang terlalu luas skema penelitiannya sedangkan yang sesuai dengan kriteria inklusi dan eksklusi ada terdapat 4 artikel yang selanjutnya akan dilakukan review. Adapun strategi literatur dapat dilihat dari gambar berikut: 


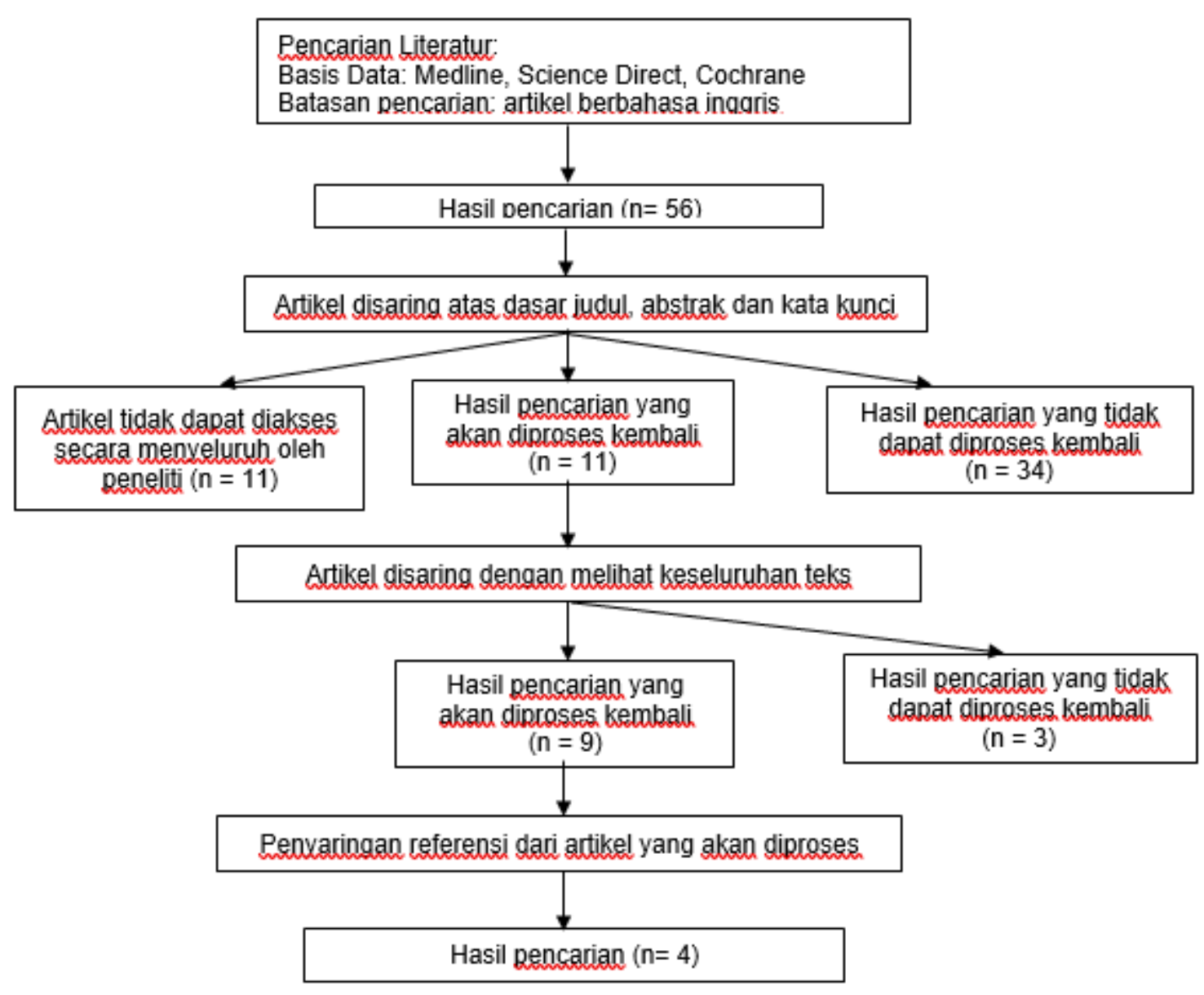

Gambar 1.

Tahapan Literatur Review dengan PRISMA

Artikel yang layak untuk review tersebut dilakukan di berbagai negara dengan berbagai metode diantaranya satu artikel kohort retrospektif, satu artikel kohort prospektif, dua artikel cross sectional (potong lintang). Setelah dilakukan pengkajian pada kualitas artikel dikategorikan high dan selanjutnya dilakukan ekstraksi data berdasar nama penulis, judul, tujuan, metode penelitian, dan hasil. Ektraksi data dapat dilihat pada tabel berikut:

Tabel 1.

Hasil Ekstrasi Data Artikel

\begin{tabular}{|c|c|c|c|c|c|c|}
\hline No. & Penulis & Judul - Tahun & Jurnal & Tujuan & Metode & Hasil \\
\hline 1. & $\begin{array}{l}\text { Lixia Yang, } \\
\text { Shilei Pan, } \\
\text { Yufeng Zhou, } \\
\text { Xiaoyang } \\
\text { Wang, Aikai } \\
\text { Qin, Yuxin } \\
\text { Huang, Suxia } \\
\text { Sun. }\end{array}$ & $\begin{array}{l}\text { The } \\
\text { Correlation } \\
\text { Between } \\
\text { Serum Vitamin } \\
\text { D Deficiency } \\
\text { and Preterm } \\
\text { Birth - 2016. }\end{array}$ & $\begin{array}{l}\text { Medical } \\
\text { Science } \\
\text { Monitor. } \\
\text { (indexed by } \\
\text { Scopus) }\end{array}$ & $\begin{array}{l}\text { Untuk } \\
\text { menganalisis } \\
\text { efek } \\
\text { defiseinsi } \\
\text { vitamin } \\
\text { pada } \\
\text { persalinan } \\
\text { premature. }\end{array}$ & 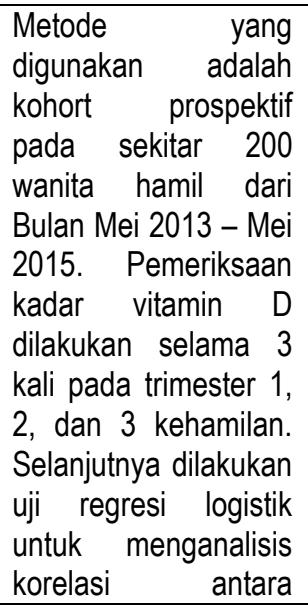 & $\begin{array}{l}\text { Pemeriksaan kadar } \\
\text { serum vitamin D } \\
\text { dilakukan berdasar } \\
\text { karakteristik dan tidak } \\
\text { ditemukan perbedaan } \\
\text { yang signifikan dari } \\
\text { usia, kebiasaan } \\
\text { merokok/konsumsi } \\
\text { minuman alkohol, } \\
\text { tingkat pendidikan, } \\
\text { IMT, dan kelompok } \\
\text { sampel yang bersalin } \\
\text { prematur serta } \\
\text { kelompok sampel } \\
\text { bersalin aterm. }\end{array}$ \\
\hline
\end{tabular}




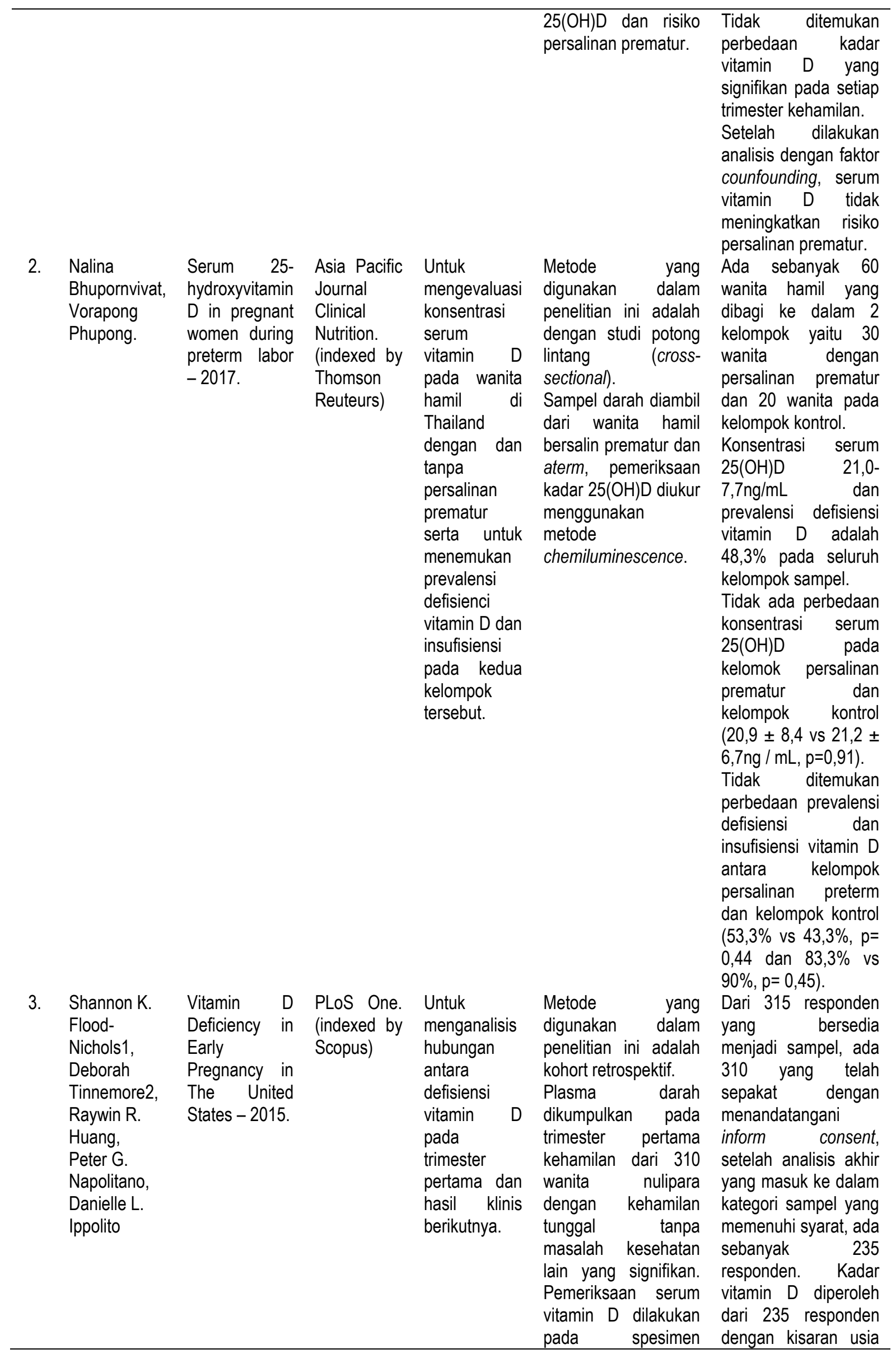




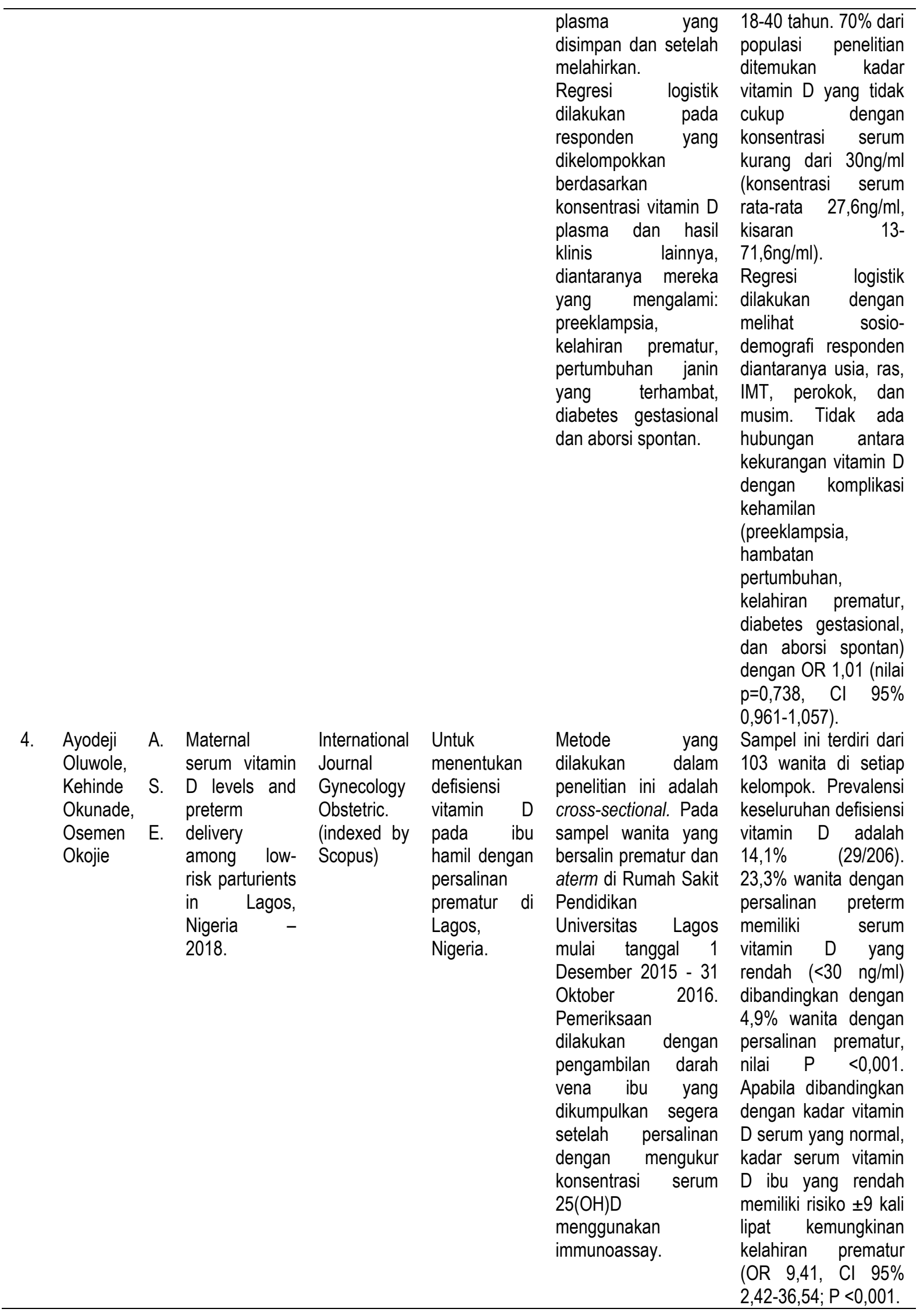

\section{PEMBAHASAN}

Vitamin $D$ adalah vitamin yang larut dalam lemak, vitamin $\mathrm{D}$ paling utama didapatkan dari paparan sinar matahari dan ditemukan secara alami dalam beberapa makanan, seperti minyak hati ikan, kuning telur, dan hati (Heaney, R. P., Davies, K. M., 
Chen, T. C., Holick, M. F., \& Barger-Lux, 2003). Ada dua bentuk vitamin $D$ yang aktif secara fisiologis yakni D2 dan D3. Vitamin D2 (ergocalciferol) yang disintesis oleh tanaman sementara vitamin D3 (cholecalciferol) diproduksi di bawah kulit dari 7dehydrocholecalciferol setelah terpapar sinar ultraviolet B (UVB) (Deluca, 2018). Holick et al., (2011) kadar vitamin D serum (dalam bentuk 25 $(\mathrm{OH}) \mathrm{D})$, dibagi dalam empat kategori sesuai dengan standar internasional, diantaranya: normal ( $\geq 30 \mathrm{ng} / \mathrm{ml})$, tidak cukup $(20-30 \mathrm{ng} / \mathrm{ml})$, defisiensi ringan (10 - 20ng/ml), dan sedang hingga defisiensi berat $(<10 \mathrm{ng} / \mathrm{ml})$. Penelitian yang dilakukan oleh Wang (2016)

Hasil statistik menunjukan tidak adanya perbedaan yang signifikan antara $25(\mathrm{OH}) \mathrm{D}$, 25(OH)D2, and 25(OH)D3 pada setiap trimester kehamilan. Hal tersebut berbeda dengan penelitian yang dilakukan di Jepang, kadar $25(\mathrm{OH}) \mathrm{D}$ berbeda secara signifikan pada kelompok persalinan prematur dibandingkan dengan kelompok persalinan aterm (Shibata, et., al., 2011). Penelitian yang sama juga dilakukan di Amerika yang menemukan wanita hamil dengan kadar $25(\mathrm{OH}) \mathrm{D}$ $>75 \mathrm{ng} / \mathrm{ml}$ memiliki insiden persalinan prematur yang lebih sedikit (Bodnar et al., 2013).

Berdasar hasil tersebut maka defisiensi vitamin $\mathrm{D}$ memengaruhi persalinan prematur. Namun, apakah vitamin $D$ memainkan peran langsung atau tidak dalam mengatur hormonal wanita hamil masih belum dijelaskan. Selain itu, kadar vitamin $D$ menunjukkan pola musiman dengan sintesis UVB lebih tinggi pada musim panas karena lebih banyak terpapar sinar matahari. Kompleksitas geografis seperti itu membuat keterbatasan membandingkan hasil penelitian yang berbeda. Keterbatasan penelitian ini terletak pada ukuran sampel yang relatif kecil dan confounding faktor dalam penelitian harus diperhitungkan. Penelitian yang dilakukan Bhupornvivat \& Phupong (2017)

Hasil statistik menunjukan tidak ada perbedaan prevalensi defisiensi dan insufisiensi kadar vitamin D pada wanita bersalin prematur dan kelompok kontrol. Meskipun secara statistik tidak ada perbedaan antara 2 kelompok sampel, akan tetapi peran vitamin $D$ dalam persalinan prematur sangat penting karena fungsinya dalam mengatur respon imun yang dimediasi sel, sehingga kekurangan vitamin D selama kehamilan dapat meningkatkan peradangan pada wanita hamil dan meningkatkan risiko kelahiran prematur.

Hasil di atas, bila dibandingkan dengan penelitian yang dilakukan di sesama Asia yakni di Jepang sangat berbeda, prevalensi kejadian defisiensi vitamin D sebesar $89,5 \%$ dengan standar deviasi sebesar $14.5 \pm 5.0 \mathrm{ng} / \mathrm{ml}$, sedangkan di Thailand ada sebesar $48,3 \%$ prevalensi kejadian defisiensi vitamin $\mathrm{D}$ dan standar deviasi konsentrasi serum $25(\mathrm{OH}) \mathrm{D}$ sebesar $21.0 \pm 7.5 \mathrm{ng} / \mathrm{ml}$ (Shibata et al., 2011). Kejadian itu dimungkinkan karena perbedaan letak geografis dan populasi, BangkokThailand berada di garis lintang $13^{\circ}$ sedangkan Jepang ada pada garis lintang $35,5^{\circ}$ dengan demikian Thailand lebih banyak terpapar sinar matahari dibandingkan dengan Jepang. Posisi atau letak geografis suatu negara juga tentu akan menentukan perbedaan prevalensi defisiensi vitamin D.

Keterbatasan dalam penelitian ini adalah penggalian informasi tentang asupan makanan/nutrisi dan paparan sinar matahari. Penelitian yang dilakukan Nichols, Tinnemore Shannon K \& Huang (2012)

Hasil statistik penelitian ini tidak menunjukan adanya pengaruh kadar serum $25(\mathrm{OH}) \mathrm{D}$ pada proses kehamilan maupun persalinan prematur. Hal ini dikarenakan dalam penelitian ini dilakukan kepada wanita nullipara, usia reproduksi sehat (24.3 \pm 4.4 tahun), dan memiliki risiko relatif rendah untuk mengalami komplikasi kehamilan.

Tetapi, prevalensi kejadian defisiensi vitamin $\mathrm{D}$ pada wanita usia muda dalam penelitian ini ada sebesar $74 \%$. Prevalensi defisiensi vitamin D pada usia reproduksi wanita tampaknya meningkat di seluruh dunia selama dua dekade terakhir, sehingga menguatkan penelitian ini (Looker et al., 2008).

Keterbatasan penelitian ini seharusnya terfokus kepada wanita reproduksi sehat sehingga peneliti menyarankan untuk selanjutnya perlu penelitian lanjutan tentang hipovitaminosis $D$ dalam kehamilan dan kesehatan reproduksi. Penelitian Oluwole, Okunade, \& Okojie (2019)

Hasil statistik menunjukan prevalensi defisiensi vitamin $D$ relatif rendah pada ibu melahirkan di Lagos-Nigeria dan ada kemaknaan secara statistik ibu hipovitaminosis $D$ dengan persalinan prematur. Peneliti mengakui bahwa dalam penelitian ini dipilih populasi wanita yang berpendidikan dan cenderung melakukan diet yang kaya akan vitamin $D$ dan nutrisi lain dibandingkan dengan wanita yang melahirkan di luar fasilitas kesehatan.

Temuan ini didukung oleh meta-analisis sebelumnya yang menemukan bahwa kekurangan vitamin $D$ merupakan faktor risiko yang signifikan untuk kelahiran premature (Lu-Lu Qin, Fang-Guo Lu, Sheng-Hui Yang, 2016). Penelitian lain 
menunjukkan kekurangan serum 25(OH)D lebih tinggi di antara wanita berkulit gelap daripada di antara wanita kulit yang lebih terang, karena wanita dengan kompleksi kulit gelap memiliki lebih banyak melanin yang melindungi kulit terhadap kerusakan akibat paparan UVB dibandingkan dengan wanita berkulit putih (Thota et al., 2013).

Keterbatasan dalam penelitian ini adalah hubungan sebab dan akibat tidak dapat ditentukan karena desain penelitian yang digunakan serta dalam mengekstraksi informasi yang dapat dipercaya tentang asupan diet vitamin $\mathrm{D}$ dari responden yang diteliti dan faktor ini mungkin memiliki pengaruh langsung atau tidak langsung pada hubungan yang dianalisis dalam penelitian.

\section{KESIMPULAN}

Meskipun secara statistik tidak terdapat perbedaan signifikan antara kadar serum $25(\mathrm{OH}) \mathrm{D}$ yang rendah dengan kejadian persalinan prematur. Akan tetapi, angka prevalensi kejadian serum $25(\mathrm{OH}) \mathrm{D}$ yang rendah ditemukan pada wanita yang bersalin prematur.

Maka dari itu sebagai negara tropis, Indonesia yang sepanjang tahun mendapat sinar matahari yang cukup, kebutuhan vitamin $D$ bisa didapat dengan terpapar sinar matahari (UVB) setiap pagi menjelang siang. Vitamin $D$ diperlukan tubuh dalam hal ini ditujukan wanita pada usia reproduktif yang sedang mempersiapkan kehamilan untuk menguatkan sistem imun dan penguatan otototot dalam organ sistem reproduksi sehingga saat kehamilan terjadi otot rahim akan kuat dan persalinan akan terjadi pada usia cukup bulan (aterm).

\section{SARAN}

Kebutuhan vitamin $D$ sangat penting dimiliki oleh wanita usia subur dalam persiapan kehamilan untuk menunjang kesejahteraan kesehatan ibu dan calon bayi. Perlu dilakukan penelitian lebih lanjut khususnya di Indonesia baik di perkotaan maupun pedesaan mengenai kandungan serum 25(OH)D dengan melihat karakteristik dari ibu hamil serta lingkungannya.

\section{DAFTAR PUSTAKA}

Bhupornvivat, N., \& Phupong, V. (2017). Serum 25hydroxyvitamin $D$ in pregnant women during preterm labor. Asia Pacific Journal of Clinical Nutrition, 26(August 2015), 287290. https://doi.org/10.6133/apjcn.112015.11

Bodnar, L. M., Ph, D., Rouse, D. J., Momirova, V., Peaceman, A. M., Sciscione, A., ... Jr, J.
M. T. (2013). Maternal 25-Hydroxyvitamin $D$ and Preterm Birth in Twin Gestations. American College of Obstetricians and Gynecologists, 122(1), 91-98. https://doi.org/10.1097/AOG.0b013e31829 41d9a.Maternal

Bolland, M. J., Grey, A. B., Ames, R. W., Horne, A. M., Mason, B. H., Wattie, D. J., ... Reid, I. R. (2007). Age-, gender-, and weightrelated effects on levels of 25hydroxyvitamin $D$ are not mediated by vitamin D binding protein. 2(67), 259-264. https://doi.org/10.1111/j.13652265.2007.02873.x

Deluca, H. F. (2018). Overview of general physiologic features and functions of vitamin D 1 - 4. 80(February), 1689-1696.

F Perez-Lopez, Pasupuleti, V., Mezones-holguin, E., Benites-zapata, V. A., Thota, P., Deshpande, A., \& Hernandez, A. V. (2015). Effect of vitamin $D$ supplementation during pregnancy on maternal and neonatal outcomes : a systematic review and metaanalysis of randomized controlled trials. Fertility and Sterility, 5(103), 1278-1288. https://doi.org/10.1016/j.fertnstert.2015.02. 019

Grundmann, M., \& von Versen-höynck, F. Von. (2011). Vitamin D - roles in women' $s$ reproductive health ? Reproductive Biology and Endocrinology, 9(1), 146. https://doi.org/10.1186/1477-7827-9-146

Hague, T., \& Wuister, J. D. (2018). High prevalence of vitamin $D$ deficiency in pregnant nonWestern. The American Journal Clinical Nutrition, (April), 350-353.

Harvey, N. C., Holroyd, C., Ntani, G., Javaid, K., Cooper, P., Moon, R., ... Cooper, C. (2014). Vitamin $D$ supplementation in pregnancy: a systematic review. 18(45). https://doi.org/10.3310/hta18450

Heaney, R. P., Davies, K. M., Chen, T. C., Holick, M. F., \& Barger-Lux, M. J. (2003). Human serum 25-hydroxycholecalciferol response to extended oral. The American Journal of Clinical Nutrition, 204-210.

Holick, M. F., Binkley, N. C., Bischoff-ferrari, H. A., Gordon, C. M., Hanley, D. A., Heaney, R. P., ... Weaver, C. M. (2011). Evaluation, Treatment, and Prevention of Vitamin D Deficiency : an Endocrine Society Clinical Practice Guideline. The Journal of Clinical Endocrinology \& Metabolism, 25(July), 1911-1930.

https://doi.org/10.1210/jc.2011-0385 
Kementerian Kesehatan Republik Indonesia. (2018). Riset Kesehatan Dasar Indonesia 2018 -. Jakarta.

Looker, A. C., Pfeiffer, C. M., Lacher, D. A., Schleicher, R. L., Picciano, F., \& Yetley, E. A. (2008). Serum 25-hydroxyvitamin D status of the US population: 1988-1994 compared with 2000-2004. The American Journal of Clinical Nutrition, 88(6), 15191527.

https://doi.org/10.3945/ajcn.2008.26182.Se rum

Lu-Lu Qin, Fang-Guo Lu, Sheng-Hui Yang, H.-L. X. and B.-A. L. (2016). Does Maternal Vitamin $D$ Deficiency Increase the Risk of Preterm Birth: A Meta-Analysis of Observational Studies. Nutriens, 8(5)(301). https://doi.org/10.3390/nu8050301

Nichols, Tinnemore Shannon K, D., \& Huang, R. R. (2012). Vitamin D Deficiency in Early Pregnancy. 19(3), 133A-133A. https://doi.org/10.1371/journal.pone.01237 63

Oluwole, A. A., Okunade, K. S., \& Okojie, O. E. (2019). Maternal serum vitamin D levels and preterm delivery among risk parturients in Lagos, Nigeria. Int $J$ Gynaecol Obstet., 144 (2)(June 2018), 216-220. https://doi.org/10.1002/ijgo.12719

Perez-lopez, F. R., Pasupuleti, V., Group, H. C., \& Benites-zapata, V. A. (2017). Effect of vitamin $D$ supplementation during pregnancy on maternal and review and meta-analysis of. Fertility and Sterility,
5(103),

1278-1288. https://doi.org/10.1016/j.fertnstert.2015.02. 019

Ponsonby, A., Lucas, R. M., Lewis, S., \& Halliday, J. (2010). Vitamin D status during Pregnancy and Aspects of Offspring Health. Nutriens, 2(3), 389-407. https://doi.org/10.3390/nu2030389

Scarlett, W. L. (2003). Ultraviolet Radiation: Sun Exposure, Tanning Beds, and Vitamin D Levels. What You Need to Know and How to Decrease the Risk of Skin Cancer. The Journal of The American Osteophatic Association.

Shibata, M., Suzuki, A., \& Sekiya, T. (2011). High prevalence of hypovitaminosis $D$ in pregnant Japanese women with threatened premature delivery. Journal of Bone and Mineral Metabolism, 29 (5), 615-620. https://doi.org/10.1007/s00774-011-0264-x

Thota, C., Menon, R., Fortunato, S. J., Brou, L., Lee, J., \& Al-hendy, A. (2013). 1 , 25Dihydroxyvitamin $D$ Deficiency Is Associated With Preterm Birth in African American and Caucasian Women. 21(2). https://doi.org/10.1177/1933719113493513

van Schoor, N., \& Lips, P. (2018). Worldwide Vitamin D Status. In Vitamin $D$ (Fourth Edition) (Vol. 2, pp. 15-40). https://doi.org/10.1016/B978-0-12-8099636.00059-6

Wang, X. (2016). The Correlation Between Serum Vitamin D Deficiency and Preterm Birth. 4401-4405.

https://doi.org/10.12659/MSM.898117 